\title{
THE RESPONSIBILITY IN PROTECTING THE ROHINGYA REFUGEES IN ACEH PROVINCE, INDONESIA: AN INTERNATIONAL REFUGEES LAW PERSPECTIVE
}

\author{
Adwani Adwani* \\ Rosmawati Rosmawati** \\ M. Ya'kub Aiyub Kadir***
}

\begin{abstract}
The coast of western Indonesia (Aceh province) has been the entrance for Rohingya refugees since 2012. At the beginning of 2020, the Rohingya refugees continued to arrive, although some of them have been resettled and transferred to the third countries. The Indonesian government rejected a large number of Rohingya refugees because there were no lex specialis in the Indonesian immigration arrangement related to asylum seekers and refugees. Historically, Indonesia was a country with commitment and experiences in dealing with refugees, however to date, Indonesia refused to become a party to the 1951 International Refugee Convention and 1967 Protocol on Refugees. Hence, there is no legal standards of the refugee management in Indonesia, and thus it complicates the management of the incoming Rohingyas. Responding to such issue, the government has issued the Presidential Regulation Number 125 of 2016 concerning the foreign refugee management to provide a temporary legal standard for all forms of refugee protection in Indonesia. However, such regulation has yet to comprehensively settled the management of the Rohingya people in Indonesia, particularly in Aceh province. This paper strongly advocates the Indonesian government to ratify the 1951 International Refugee Convention as to protect and settle the refugee under the non-refoulment principle which is fundamentally referred to humanitarian values.
\end{abstract}

\footnotetext{
* Fakultas Hukum Universitas Syiah Kuala (USK). Email: adwani@unsyiah.ac.id.

** Fakultas Hukum Universitas Syiah Kuala (USK). Email: rosmawati@unsyiah.ac.id.

*** Fakultas Hukum Universitas Syiah Kuala (USK). Email: m.yakub.akadir@unsyiah.ac.id.
} 
Keywords: humanitarian responsibility, protection of refugees, Rohingya refugee, international refugee law, principle of non-refoulement.

\title{
TANGGUNGJAWAB MEMELIHARA PELARIAN ROHINGYA DI PROVINSI ACEH: SATU PERSPEKTIF DARI UNDANG-UNDANG PELARIAN ANTARABANGSA
}

\begin{abstract}
ABSTRAK
Pantai barat Indonesia (Provinsi Aceh) telah menjadi titik kemasukan pelarian Rohingya dari 2012. Pada awal tahun 2020, pelarian Rohingya terus memasuki, walaupun ada diantara mereka yang telah ditempatkan semula dan di pindahkan ke negara ketiga. Kerajaan Indonesia telah menolak ramai dari pelarian Rohingya kerana tiasa lex specialis dalam susunan imigrasi Indonesia berkaitan pelarian dan pencari suaka. Pada masa lampau, Indonesia merupakan salah satu negara yang mempunyai komitmen dan pengalaman dalam menangani masalah pelarian. Walau bagaimana pun, pada waktu ini, Indonesia tidak mahu menjadi parti kepada Konvensyen Antarabangsa Pelarian 1951, serta Protokol Konvensyen Pelarian 1967. Oleh itu, tiada standard undang-undang mengenai pengurusan pelarian di Indonesia. Ini menyulitkan pengurusan pelarian Rohingya yang memasuki Indonesia secara berterusan. Bagi menangani masalah tersebut, kerajaan telah mengeluarkan Peraturan Presiden Nombor 125 tahun 2016 mengenai pengurusan pelarian bagi menetapkan standard undang-undang untuk pelbagai jenis perlindungan pelarian di Indonesia. Malangnya, peraturan tersebut belum lagi dapat menyelesaikan masalah pengurusan pelarian Rohingya di Indonesia secara menyeluruh, lebih-lebih lagi di provinsi Aceh. Makalah ini ingin menyarankan kepada kerajaan agar meratifikasi Konvensyen Antarabangsa Pelarian, 1951 agar dapat melindungi dan menyelesaikan isu pelarian dibawah prinsip non-refoulement yang secara dasarnya merujuk kepada nilai kemanusiaan.
\end{abstract}

Kata kunci: tanggungjawab kemanusianaan, perlindungan pelarian, pelarian Rohingya dan undang-undang antarabangsa pelarian, prinsip non-refoulement.

\section{INTRODUCTION}

Tens of thousands of Rohingyas have fled Myanmar. Many have landed on the coast of the Aceh province of Indonesia in 2012. The 
highest peak of refugee flows occurred in 2015 and continued until early $2020 .{ }^{1}$ For Indonesia, especially Aceh, the management of the Rohingya refugees has not yet been accomplished even though it has tried to provide an immigration detention centre handled by the Community House ("the House"). The Houses, however, are inappropriate because the facilities are not intended as the Houses to accommodate foreign refugees but are instead a temporary prison for foreigners involved in illegal migrant violations.

The detention house is inadequate for refugees for some reasons, ${ }^{2}$ including the limited quantity available and the lack of facilities (such as bedrooms and toilets) for the number of refugees entering Indonesia with an unknown deadline. The management of refugees in Indonesia should only be temporary, an initial treatment, followed by the program resettling them in a third country that ratifies the convention, ${ }^{3}$ because Indonesia has not ratified the Refugee Convention 1951 (1951 Convention) and the Protocol Relating to the Status of Refugee 1967 (1967 Protocol).

Below are the justifications for intense dealing with refugees in Indonesia:

1. Indonesia is referred to as a transit country for its strategic location in the marine traffic connecting Asia

1 Crystal Liestia, “76 Muslim Rohingya Berlabuh di Bireun,” Republika, accessed April 18, 2020, http://www.republika.co.id/berita/duniaislam/islam-nusantara/18/04/20/p7hf8m313-76-muslim-Rohingyaberlabuh-di-bireun.

2 Many obstacles are faced after sheltering the refugees, including the national regulation, stakeholders related to refugees, funding, assimilation, and the feasibility of living in houses that do not meet the standard. The houses look like prisons for immigration criminals without proper sanitation, such as in Aceh where refugees temporarily accommodated in the fish auction center (TPI), the primary market where fishes are collected from the sea by fishermen.

3 Norman Edwin Elnizar, “Ada Masalah Regulasi Penanganan Pengungsi di Indonesia," Hukum Online, accessed July 26, 2017, https://www.hukumonline.com/berita/baca/lt597853eb3280a/there\%20is $\% 20 \mathrm{a} \% 20$ problem-regulation-handling-refugees-in-Indonesia. 
to Australia and America, and joining the Indian and Pacific oceans. ${ }^{4}$

2. Historically, Indonesia was well known for its efforts in handling the refugees on Galang Island for a long period, resulting it to be well known as a country committed to solving the foreign refugee issues. ${ }^{5}$

3. Humanitarian reasons that are established in the 1945 Constitution of the Republic of Indonesia; Law on Human Rights (HAM) Number 39 of 1999; Decree of the People's Consultative Assembly (MPR) No. XVII / MPR / 1998 concerning human rights; Presidential Decree Number 38 of 1979 concerning the coordination in resolving the problem of Vietnamese refugees in Indonesia; Ministry Circular Letter Number 11 / RI / 1956 concerning the protection of political asylum seekers; and finally the Presidential Regulation Number 125 of 2016 concerning the management of foreign refugees.

4. Due to specific religious and customary aspects of the region, in the case of Rohingya refugees arriving at the Aceh coast, the refugees were welcomed by Acehnese whose customs are glorifying guests and helping fellow Muslims brothers or sisters experiencing calamity. It is also the practice of the customary marine institution (the sea commander and fishermen in assisting humans who are stranded at sea). ${ }^{6}$ Even though in 2015 the government had refused a large number of refugees coming to Indonesia for security and juridical reasons (the absence of lex specialis regulation in immigration)

4 Intan Pelangi, "Protection of Asylum Seekers Under Law Number 39 Year 1999 Concerning Human Rights," Journal of Legal Studies 4 no. 1 (2017): 143-144.

5 The interview with the sea commander in illegal fishing research the explanation of duties and functions of the customary marine institution, sea commander and fishermen in June, 2017.

6 Sophia Listriani, Rosmawati and M. Ya'kub Aiyub Kadir, "Toward a New Legal Framework for Settling Rohingya's Refugee Crisis in Indonesia: A Lesson Learned from Aceh Province," Advances in Social Science, Education and Humanities Research 413 (2019): 227-285. 
as well as the domestic economic issues and the status of Indonesia as a non-ratifying convention country, the government remains concerned on the management of refugees entering the country from 2015 to date. ${ }^{7}$

5. Aceh has experienced a long-standing conflict, where being a refugee both in domestic and international settings was common. This feeling made Acehnese to be more empathetic towards what happened to the Rohingyas, so that the attitude of the Acehnese people was considered to be uniquely conservative. For this specific reason, from 2012 to 2015 , several groups of Rohingya were accommodated in Kuala Langsa, Bireun, and other places by fishermen. ${ }^{8}$

The previous explanation generates two main research problems to study, including, to what extent is the government of Indonesia being responsible in dealing with Rohingya refugees in the Aceh province according to international refugee law and what are the obstacles experienced by the Indonesian government in dealing with Rohingya refugees in Aceh?

\section{METHOD AND DATA}

This study was doctrinal research using secondary data, a comprehensive and analytical study of both primary and secondary legal materials using a statute, a conceptual approach and observatory of the situation of Rohingya people in Aceh province. The data was analyzed qualitatively by describing the research data as systematic exposure to obtain an overview of the problems being the focus of the study. The results of the analysis were deductively concluded.

7 Rosmawati, "Protection of Refugees / Seekers in Indonesia (As a Transit State) According to the 1951 Convention and 1967 Protocol", Kanun Jurnal Hukum Hukum, no. 67 (2015): 470-474.

8 Antje Missbach, Facets of Hospitality: Rohingya Refugees' Temporary Stay in Aceh (New York: Cornell University Press, 2017), 42-43. 


\section{RESULTS}

\section{The Government Responsibility for the Rohingya Refugees in Aceh.}

The 1951 Convention defined refugees as people who are outside their countries and forced to leave their home countries because of events causing them fear and distress for their race, religion, ethnicity, nationality, and/or political reasons; and certain social groups that contradict the politics of the ruler in their home countries leading to these people to leave their borders seeking asylum. ${ }^{9}$ Fear is a fundamental reason for international refugees distinguishing them from other types of refugees or migrants who may generally have similar conditions to the international refugees, stranded and in need of help from other countries, but leave the country solely for economic, war, or natural disaster reasons. For such conditions, they are also eligible for humanitarian assistance. ${ }^{10}$ International refugees refer to the English term "Refugees", which has been stated in the 1951 Convention and 1967 Protocol as a group of people who cannot rely on the protection from the countries obliged to guarantee their safety. These people need special attention, preparation, and special management from the international community. ${ }^{11}$

Countries or the international community have rights and obligations and are responsible for protecting their citizens who are in other countries and vice versa is obliged to protect citizens of other countries in their countries. ${ }^{12}$

Concerning a condition that refugees who fled to a particular country, the obligation to protect is not solely the country of origin's task, but to other countries or the international community. Within this

9 Jawahir Thontowi, Law and International Relation (Yogyakarta: UII Press, 2016), 191.

10 Susan Martin, "Forced Migration, the Refugee Regime and the Responsibility to Protect," Global Responsibility to Protect (February 2010), 39.

11 Sulaiman Hamid, Asylum Institute in International Law (Jakarta: Rajawali Press, 2002), 42.

12 Sefriani, An Introduction to International Law (Jakarta: Raja Grafindo Persada, 2011), 283. 
framework, the international community must be responsible for taking action to protect these refugees. ${ }^{13}$

The obligation to protect refugees is mainly borne by the State or the government. Besides, it is also carried out by the international community such as the UNHCR and the International Organization for Migration (IOM). Hence, these parties must play a role in protecting refugees who have been temporarily displaced to a country.

People who experience torture, ill-treatment, or safety threats in their country due to political conflict are displaced to another country. They generally flee to other countries with the expectation that these countries will receive them and can guarantee their human rights for their better future. The willingness of refugees to look for a new place or country is a series of human rights that must be respected and guaranteed under International Refugee Law. ${ }^{14}$

Indonesia has been visited by refugees due to its strategic location. Refugees in Indonesia were first associated with the problem of refugees in the period 1975-1980, namely Vietnamese refugees who were accepted by Indonesia and placed in the Riau Province precisely on Galang Island. ${ }^{15}$

It is noted that the country of origin has no means of protecting the refugees because the refugees have left their home to another country. In this connection, the international community is carrying out the responsibility to protect these refugees. Therefore, UNHCR promotes protection activities and assistance programs together with its partners in the context of refugees and asylum seekers meeting basic

13 Adwani, "The Function of the International Community in Protecting International Refugees, Especially Rohingya Refugees", in Webinar at the Unsyiah Faculty of Law National Seminar (Banda Aceh, 2020), 3.

14 Aryuni Yuliantiningsih, "Protection of Refugees in the Perspective of International Law and Islamic Law (Case Study of Rohingya Boat People)," Journal of Legal Dynamics 13, no. 1 (January 2013): 160.

15 Sicilia Mardian Yo'el, "Juridical Study of Refugee Protection in Indonesia After the Entry into force of the Republic of Indonesia Presidential Regulation Number 125 Year 2016 Regarding Handling of Refugees from Abroad", Journal of Diversity 2, no. 2 (September 2016): 468. 
needs as long as refugees crave the most suitable problem-solving in the long term. ${ }^{16}$

Since the refugee problem is a global issue that is closely related to human rights, their arrival is not under the ordinary circumstances of immigrants traveling with complete travel documents and objectives. For example, the economic immigrants leaving their country without the fear of persecution have main focus on job seeking for better economic conditions than their home countries. ${ }^{17}$ In the case of the Rohingya refugees arriving in Aceh, their focus is not on seeking jobs. Instead, they were forced to leave their home countries due to the fear of their life safety and other rights. Some members of the 1951 Convention rejected the Rohingya refugees entering their countries between 2013 and 2018 and considered them as illegal migrants, and thus they were accepted but later expelled and their rights to obtain asylum, the refugee status, as well as other rights as refugees, were neglected. Article 33, paragraph (1) of the 1951 Convention prohibits these actions; as explained below:

No Contracting State shall expel or return (refouler) a refugee in any manner whatsoever to the frontiers of territories where his life or freedom would be threatened on account on his race, religion, nationality, membership of a particular social group or political opinion.

It is stated that no country under any condition may evict them to their home countries, which could threaten their life and freedom of race, religion, nationality, certain social groups, and political opinions. Malaysia had previously refused to land Rohingya refugees in its territory. While Indonesia has two policies, first: refusing them to land in Indonesian territory, and second: accepting them to land for a temporary time under humanitarian principles, providing them temporary shelters within a certain time limit. As it is not supported by a sufficient legal framework, the long-term treatment over refugee has been uncertain.

\footnotetext{
16 Widiarti, "Pengungsi," The UN Refugee Agency (UNHCR) Indonesia, accessed June 14, 2020, https://www.unhcr.org/id/pengungsi.

17 Susan M Akram, "Assessing the Impact of the Global Compacts in the Middle East”, International Journal of Refugee Law 30, No. 4 (2018): 693.
} 
Referring to the value and due to humanitarian reasons, Indonesia who has accepted refugees into Indonesia does not neglect or ignore these refugees. In accordance with what is stated in the Preamble of the 1945 Constitution of the Republic of Indonesia, part I, Indonesia aims to participate in carrying out world order based on social justice and eternal peace. This goal is clarified again later in Article $28 \mathrm{G}$ paragraph 2 of the body of the 1945 Constitution. Cooperation in various issues between Indonesia and other countries is always upheld. Therefore, handling international refugee should be based on refugee rights or human rights. ${ }^{18}$

On this basis, Indonesia must fully accept refugees to be accommodated, even within a certain time. But the most important consideration is not to refuse and those who have been accepted to be accommodated must not be deported to their country or who threaten their lives, due to the existence of the principle of non-refoulment under 1951 Convention.

The principle of non-refoulement is a state responsibility which ratifies the 1951 Convention so that the refugees do not return to the dangerous area. It also does not mean that refugee recipient countries are obliged to prepare their relevant residence for an extended period. The principle of non-refoulment has been accepted as customary international law. Hence, this principle applies to all countries in various regions, regardless if a country does not ratify the 1951 Convention. ${ }^{19}$

Hence, refugees cannot be returned to their countries that threaten their lives or cause extraordinary fears. This is necessary to maintain the safety of their lives. Such matter is related to the protection of human rights for the refugees. Returning refugees to their hometown which potentially threatened by their government has been questionable.

Article 14 of the Universal Declaration of Human Rights 1948 stipulated that: "Everyone has the right to seek and to enjoy in other

18 Sicilia Mardian Yo'el, “Juridical Study of Refugee Protection in Indonesia After the Entry into force of the Republic of Indonesia Presidential Regulation Number 125 Year 2016 Regarding Handling of Refugees from Abroad", Journal of Diversity 2, no. 2 (September 2016): 465.

19 Ibid, 469. 
countries asylum from persecution. ${ }^{20}$ Everyone is entitled to obtain the right and protection from the other country against the persecution threat. This reinforces that even if the country did not ratify the Refugee Convention (1957 Convention and 1967 Protocol concerning refugee status), based on humanitarian consideration, any country is responsible for accepting the Rohingya refugees. As for Indonesia, even though it has not ratified the convention concerning refugees, the country can facilitate and provide temporary shelter, ${ }^{21}$ just as the Indonesian government once supported "the boat people from Vietnam" by providing them shelter in Galang Island.

Indonesia has been cooperative with the United Nations High Commissioner for Refugees (UNHCR). In this regard, UNHCR is supervising countries that have ratified refugee conventions and protocols. Therefore, the countries in accepting asylum seekers can implement their system, as well as determine the status of refugees. On the other hand, UNHCR has the role of serving asylum seekers and providing refugee status for countries that have yet to ratify the conventions.

The most perfect codification regarding refugee rights at the international level is the 1951 Convention. It is generally known that the Government of Indonesia itself has not yet ratified the 1951 Convention and the 1967 Protocol on refugees. Based on that, Indonesia legally has not had the obligation to provide protection for international refugees or acknowledge it, as well as for refugees in Indonesia who are looking for asylum seekers.

Indonesia is one of the countries that accept and ratify the Universal Declaration of Human Rights (UDHR) which proves Indonesia's commitment to the international communities. Nevertheless, certain rules are applied by Indonesia, namely the Regulation of the Director-General of Immigration Number IMI1489.UM.08.05 of 2010 which regulates the handling of illegal

20 UN General Assembly. (1948). Universal declaration of human rights (217 [III] A).

21 "UNHCR calls for solidarity, support and solutions for Rohingya refugees ahead of an urgent donor conference", accessed on 12 October 2020, https://www.unhcr.org/news/briefing/2020/10/5f8d7c004/unhcr-callssolidarity-support-solutions-rohingya-refugees-ahead-urgent.html. 
immigrants, and Presidential Regulation 125 of 2016 which regulates overseas refugees. ${ }^{22}$

Although Indonesia has not ratified the 1951 Convention, Indonesia and other countries must respect and must not violate the provisions of the Convention. This is in line with the Calfo clause which implies to adhere to the basic provisions of international customs such as those relating to basic human rights that must be respected and protected.

In this connection, of course, States should not expel people who are in trouble, suffering, and threatened with life in their countries who seek safety and comfort to other countries. It is within this framework that it is important for Indonesia to temporarily accommodate or accept refugees who, in this case, the Rohingya people who has been suffered for a long period in their home country, Myanmar. It should be noted that the following treatment over Rohingya in Indonesia very much depend on the political decision of the Indonesia to change its policy over refugees through ratifying the 1951 Convention. In such situation the involvement of international organisation such as UNHCR and International Migrant Organisation (IOM) would be easier to support the role of government to protect the Rohingya, in particular determining their status.

The presence of Rohingya refugees in North Aceh and Lhoksemawe City, as helped voluntarily by the local community's, especially the fishing communities who persuade the Regency / City Government to provide them a basic need for emergency and humanitarian basis. Even more the such pressure situation from local community has been urged central government to issue a temporary legal framework of Presidential Degree number 125-year 2016 concerning the management of foreign refugees.

22 Ida Tuty Rakhmi, Mujibussalim, Mahfud, "Criminal Acts Conducted by International Refugees in Indonesia," Junal Kanun Legal Studies, Unsyiah Faculty of Law 21, No. 1 (2019): 145-158. 


\section{A. The obstacles experienced by the Indonesian government in managing Rohingya refugees in Aceh}

In the International Amnesty campaign for refugee rights established in March 1997, it states that the refugees are usually ignored by most countries or governments around the world: ${ }^{23}$ The Rohingya refugees in Indonesia, especially in Aceh province, had satisfied the requirements of international refugees stated in the 1951 Convention $^{24}$. Indonesia, especially the regional government of Aceh, in handling this issue, encountered some problems, including:

1. Immigration, the arrival of a large number of foreigners, without official documents, made it difficult for the immigration office to conduct preliminary assessment. The community and volunteers from certain social organisations helped to collect data on refugees. The Head of Public Relations and General Affairs, the Directorate General of Immigration mentioned in the commemoration of World Refugee Day that no law in Indonesia specifically regulates the refugee issue, the law that governs the refugee issue is the Law Number 37, 1999 (Number 37 Law) concerning the external relations. Regulation is then derived from this Number 37 Law, namely: Presidential Regulation Number 125 of 2016 concerning the management of foreign refugees. This regulation serves as the basis for the services provided by immigration officials to refugees. However, this task is burdensome for the immigration personnel who are initially not trained to be social workers dealing with humanitarian issues other than immigration (immigration law enforcement). ${ }^{25}$

23 Ahmad Romsan, Introduction to International Refugee Laws, International Law and Principles of International Protection (Jakarta: UNHCR, 2003), 17.

24 UNHCR, The State of the world's Refugees 1997-1998, A Humanitarian Agenda (New York: Oxford University Press, 1997), 51-52.

25 Norman Edwin Elnizar , "Ada Masalah Regulasi Penanganan Pengungsi di Indonesia," Hukum Online, accessed July 26, 2017, https://www.hukumonline.com/berita/baca/lt597853eb3280a/there\%20is $\% 20$ a\%20problem-regulation-handling-refugees-in-Indonesia. 
2. The issue of Rohingya refugees is a humanitarian problem that cannot be ignored, becoming a "Jus Cogen" norm and is a common problem of the international communities. Thus Indonesia chooses not to let the refugees stranded in the Indonesian sea. Indonesia has ratified the 1982 Sea Law Convention requiring any country to assist people in an emergency situation in sea. In this case, the risk of accepting refugees is to resettle the Rohingya refugees when it landed in Indonesia's territory for long term period.

3. The inadequate funds and facilities for dealing with the refugees over a long period, if not properly managed, can affect the social, cultural, ideological, and national security issues.

The obstacles in the refugee management previously described are also generally experienced by other countries, both those that have ratified the 1951 Convention and the 1967 Protocol on refugee status, or those that have not, so that they can be described through two contradictory management models:

1. Security Model ${ }^{26}$

The security model prioritises the rights of a sovereign country to accept or reject foreigners entering their country. The refugees are a threat, so they must always be controlled. This management model does not respect the refugees, both in terms of internal and external management.

2. The Individual Rights Model;

This model views refugees as individuals who must be protected by the Convention on Refugees and the doctrines of human rights, so it ignores the country's claim as the most powerful party. Therefore, the refugees get justice and protection based on human dignity. However, few social problems later arise in the area where refugees live, for example, Nigerian

26 Heru Susetyo, "Policy on Handling Internally Displaced Persons (IDPs) in Indonesia and the International World," Journal of International Law 2, no. 1 (October 2004): 159. 
refugees using the stipend from UNHCR or donor agencies for narcotics abuse or the problem of crimes committed by refugees in Indonesia. ${ }^{27}$

Another problem that arises is concerning the difference in the cultural foundation of the local community with the culture of refugees. These cultural differences are reflected in the attitude of the behaviour of the refugees who do not understand the local culture, which is sometimes difficult to adjust to their culture, so that it requires guidance and learning to refugees to be able to respect religious values and socialcultural values of the local community, so as not to cause a conflict in refugee camps.

Moreover, the unpleasant in the temporary shelter has led refugees to commit a crime and potentially used by other party for trafficking and other crimes. Such crime has contributed to lack of sympathy from community. When they commit any crime, it would be problematic for Indonesia to proceed into legal enforcement system as Indonesia has not ratified the 1951 Convention.

The ratification of the 1951 Convention and the 1967 Protocol that has not been carried out by Indonesia is a problem in dealing with the influx of refugees from other countries. However, in this case, there is no specific explanation regarding the law enforcement procedures for refugees who commit criminal acts in the 1951 Convention and 1967 Protocol. Also, special and strict regulations in handling or determining refugee status are not equipped with complete or clear documents. This is also because the 1951 Convention and its 1967 Protocol have not yet been ratified by Indonesia which regulates and organizes refugee status. ${ }^{28}$

A foreigner or refugee who enters the territory of a country must submit to and obey the rule of law as in his native country. However, some countries apply certain restrictions on foreigners or refugees. Foreigners are not given political rights but they are guaranteed with

27 Norman Edwin Elnizar , "Ada Masalah Regulasi Penanganan Pengungsi di Indonesia," Hukum Online, accessed July 26, 2017, https://www.hukumonline.com/berita/baca/lt597853eb3280a/there\%20is $\% 20 a \% 20$ problem-regulation-handling-refugees-in-Indonesia.

28 Ida Tuty Rakhmi, Mujibussalim, Mahfud, "Criminal Acts Conducted by International Refugees in Indonesia," Junal Kanun Legal Studies, Unsyiah Faculty of Law 21, No. 1 (2019): 149. 
other basic rights. ${ }^{29}$ Obviously, refugees have their rights including obtaining rights with refugee status.

Refugees have rights as well as basic human rights despite certain restrictions under applicable legal provisions in the context of promoting human rights. In this connection, it is undeniable that the United Nations has a major and important contribution to the promotion and protection of human rights in all regions of the world.$^{30}$

The guarantees for the protection of freedom or basic rights are very important based on certain circumstances such as when he is threatened with eviction, torture on religious grounds. ${ }^{31}$

These are part of the obstacles in protecting the refugees. Besides, since Indonesia has not ratified the 1951 Convention and the 1967 Protocol, in such circumstances Indonesia is not obliged to protect refugees.

\section{DISCUSSION AND CONCLUSIONS}

\section{A. Discussion}

The response of the Republic of Indonesia government, especially the regional government, in dealing with the Rohingya refugees in Aceh from 2015 to 2020 is based on the information from Acehnese fishermen coordinating with the village officials and the local law enforcement officials. The Rohingya refugees stranded in the Aceh coast were welcomed and delivered to temporary shelters on open trucks. $^{32}$ The government, the Indonesian Volunteer Society (MRI), and several philanthropic institutions such as Aksi Cepat Tanggap (ACT), Badan Amil Zakat Nasional (BAZNAS), Dompet Dhuafa,

29 Irsan Koesparmono, Internal Refugees and Human Rights (Jakarta: National Commission on Human Rights, 2007): 33.

30 Boer Mauna, International Law Definition, Role and Function in the Era of Global Dynamics (Bandung: Alumni Original, 2000), 601.

31 Irsan Koesparmono, Internal Refugees and Human Rights (Jakarta: National Commission on Human Rights, 2007): 3.

32 Rosmawati, "Protection of Refugees / Seekers in Indonesia (As a Transit State) According to the 1951 Convention and 1967 Protocol", Kanun Jurnal Hukum Hukum, no. 67 (2015):.472-473. 
Rumah Zakat Indonesia (RZI), and Mer-C, provided aid to Rohingya refugees. ${ }^{33}$

The Presidential Regulation Number 125, 2016 concerning the foreign refugee management was issued even though the regulation required to be reviewed for the technical implementation, budgeting, and refugee shelter facilities with appropriate operating standards and detention centre services. Besides, a meeting of the Indonesian foreign minister and the neighbouring countries such as Malaysia and Thailand to discuss the Rohingya refugees' management is essential. Also, it is necessary to appeal to the UNHCR to play an active role in dealing with the Rohingya refugees, without merely leaving the current host country alone to tackle this problem.

The Presidential Regulation (PR) of the Republic of Indonesia Number 125/ 2016 concerning the Handling of Refugees is the temporary breakthrough, a legal source to treatment for Rohingya Refugee in the Aceh province. This PR contains key definitions and sets out process for the detection, shelter and safeguarding of Refugee and asylum-seekers. Article 2 (1) of the PR states that:

the handling refugees are carried out to cooperation between the central government and the United Nations through the United Nations High Commissioner for Refugees in Indonesia and/or international organizations.

Indonesia, in the People's Consultative Assembly (MPR) Decree No. XVII / MPR / 1998, Article 24, states that "everyone is entitled to seek asylum to obtain political protection in other countries." Also, article 2 stipulates orders to the President and Parliament to ratify the instruments related to the rights of refugees without conflicting the main five principles of Indonesian state ideology, called 'Pancasila'. ${ }^{44}$ In practice, managing thousands of refugees is not an easy task for the

33 Rahmad Fajar, "RZ Siap Salurkan Bantuan Pembaca Republika ke Pengungsi," Republika, accessed April 18, 2020, http://www.republika.co.id/berita/duniaislam/wakaf/18/04/20/p7hjbu396-rz-eady-to-distribute-readersrepublika-to-refugee.

34 Michael Morfit, "Pancasila: The Indonesian State Ideology According to the New Order Government", Asean Survey, Vol. 21, No. 8 (Aug., 1981): 838-851. 
Government of the Republic of Indonesia. The immigration authorities, which have not been evenly equipped with offices in the districts where the refugees land, lead to the procedural management of the refugees being neglected. This issue raises new legal problems related to crime, and other humanitarian management problems, such as the reporting system. It should directly involve the immigration office to register. However, the reporting starts from the nearest police station to the headquarters of the Republic Indonesia National Police, and the Ministry of Foreign Affairs before coordinating with the representative of the UNHCR.

The UNHCR has not played its role well in dealing with Rohingya refugees in Aceh. Only condemning the countries rejecting the Rohingya refugees is not enough, the UNHCR is expected to take more concrete steps. The influx of he Rohingya refugees into Indonesia, especially in Aceh, may not be defined as prospering instability within the Indonesian states. In the event of a lack of uncertainty in the supervision of refugees in Indonesia as well as the uncertain status of refugees, it will be increasingly difficult to realise their protection. If the refugees are not handled properly, over time they may be the source of problems that can harm Indonesian; politically, economically, socio-culturally, and religiously.

In reality, refugees continue to arrive, and this is accompanied by refugee behaviour, for example doing acts that violate those classified as criminal acts or violate the laws in force in the country where refugees are staying. An example was identified in 2009, when a group of Rohingya refugees were transported to Medan by the UNHCR because the refugees committed criminal acts of destroying the public facilities, fighting, and theft. ${ }^{35}$

Rohingya statelessness raises a legal question of which law constitutes their personal status in the absence of their nationality. According to Article 7 of Indonesian Citizenship Law Number 12 Year 2006 (Law No 12/2006), which stated that "all persons who are not citizens of the Republic of Indonesia shall be treated as alien," with or without nationality, foreign refugees, including refugees and/or asylum seekers, are considered as 'Orang Asing'. Aside from international

35 Kadarudin, "The Linkage Between Stateless Persons, Asylum Seekers, and Refugees. Makassar," Gratia Journal 8, no. 1 (2012): 123. 
private law provision in $16(\mathrm{AB}), 3625$, Indonesia did not have specific regulation of the personal status of aliens, in this case, refugees and/or stateless persons.

Under selective policy of immigration approach now Indonesia treats refugees in the context of foreign relations law, under the security and territorial sovereignty perspective, rather than human rights based. Indonesia has lack of capacity to cope with Myanmar and other refugees, as it has no clear legal framework, lack of national budget allocation, and lack of coordination among stakeholders. The undergoing challenges are; an increased trend of foreign refugee influx (due to prolonged conflicts, limited shelters, constrained budget of the international organizations (UNHCR and IOM), low rate of the implementation of durable solutions (voluntary repatriation and resettlement to the third countries) and an increasing impact of Refugee's presence on Economic, Social, Cultural, and Security.

It is hard for the government officials to properly handle the refugees due to the limited primary duties and functions of the immigration office as stipulated in Law Number 6 of 2011. This is a major polemical issue for the Indonesian government in resolving the refugee issues. There is no legality in action while this human rights issue requires immediate action.

The inexistence of legal standards leads to the unavailability of the budget allocated to the refugee management, which in turn becomes one of the constraints for the immigration officers. It is then obvious the limited working space, in terms of the legal standards, budget/ finance, as well as the issue of primary duties and functions, are the obstacles experienced by stakeholders.

Financial support is very crucial aspects and it is unfair for local government to cover all the expenses. Article 40 of Presidential Regulation 125 says that the budget comes from national budget of each related ministries, and other source of relevant budget.

This article needs to be revised to anticipate the experience in Aceh. Central government could assign each ministry to allocate budget to anticipate refugee crisis. Since Rohingya refugees arrived in Bireuen in 2015, all the ministries assigned have still not submitted the

36 Dutch East Indies, Algemene Bepalingen van Wetgevingvoor Indonesie (AB), Staatblad 1847, No. 23: Art. 16. 
allocation budget for refugees. UNHCR also should actively assist and support the government to solve budgeting problem.

Indonesia, a country that has not ratified the convention, may decide between the following two options. First, it may reject the refugees for there is no specific regulation to regulate refugees and prevent the current social and economic burden for the government. Second, it may accept the refugees for the sake of humanity and provide temporary shelters for the Rohingya refugees, as what was done with the Vietnamese refugees. The second option does not necessarily enable Indonesia to grant refugee status to the Rohingya refugees, even though they are eligible based on the 1951 Convention and 1967 Protocol. In this case, UNHCR has the authority to establish the procedures for these groups of people to obtain the "refugee" status.

Some suggest that each country should prioritise the humanitarian values concerning the international refugee issue by accommodating each refugee stranded in the middle of the ocean and landing them in the country. Each country can provide temporary shelters for the refugees, like the shelter for the Vietnamese refugees in aftermath of Indonesian independence, on an empty island (Galang Island). Furthermore, the neighbouring countries such as Malaysia, Thailand, and Myanmar, as well as the UNHCR, can jointly support the financing of refugee management. Following this, the UNHCR is responsible for sending them to the countries who are willing to offer them citizenship.

The Myanmar government must change its policies discriminating against the Rohingya ethnic groups to stop the refugees fleeing to other countries. The countries ratifying the convention should conduct their obligation as an international community on the international refugee issues. The UNHCR involves the role of organisations in Asia such as ASEAN in bringing about regional stability and collaboration in matters of mutual interest. ${ }^{37}$

In general, every person in trouble must receive protection, including those who have fled to other countries. Therefore, Rohingya refugees who fled to Indonesia need to be accepted as intended by the principle of non-refoulment in the 1951 Convention. The principle of

37 Susan Kneebone, "The Bali Process and Global Refugee Policy in the Asia-Pacific Region,” Journal of Refugee Studies 27, no. 4 (2014): 614615. 
non-refoulment as a fundamental concept or principle protected by the international community to asylum seekers and refugees, that the State cannot return refugees to their home country or send asylum seekers back to an area that threatens the safety and life of refugees or people seeking asylum. ${ }^{38}$

Fortunately, the Rohingya refugees in Aceh were accepted by the local community and supported by the regional Government of North Aceh and Lhoksemawe City. Refugees are temporarily accommodated in Aceh to find other countries that receive them, which are usually facilitated by UNHCR.

Such local people treatment contrasts to the rejection and resistance of Indonesia not to ratify the 1951 Convention and the 1967 Protocol on Refugee status. However, the government and the community provide protection in any way they can. Whereas, regarding refugee status for the refugees, efforts were made by UNHCR and also with the assistance of IOM. Certainly, the status determination usually experiences obstacles in finding another State that is willing to accept them, which is usually time consuming.

Until now, the Rohingya refugee's problem has not gotten a bright spot because it is still spreading in many places, including Indonesia. Even in Bangladesh, the number of Rohingya refugees has reached 160 million people, and the state of Myanmar is still delaying and postponing their repatriation time. Indonesian Foreign Affairs Minister, Retno Marsudi, revealed that one concrete step that could be done to help the Rohingya issue was to prepare an environment that supports refugees so that they can return to Myanmar. Countries in the world which are facilitated by the United Nations also continue to hold meetings and coordination to determine steps that can be taken to overcome the problem or issue of Rohingya.

\section{B. Conclusion}

Every refugee has their basic rights that must be protected under humanitarian sense, as formulated in terms of the 'non-refoulment' principle under international refugee law. However, several states have

38 Ida Tuty Rakhmi, Mujibussalim, Mahfud, "Criminal Acts Conducted by International Refugees in Indonesia," Junal Kanun Legal Studies, Unsyiah Faculty of Law 21, No. 1 (2019): 151. 
not formally ratified such convention, including Indonesia, so local community initiative in the Aceh Province has forced the central government to formulate a Government Regulation 125/2016, which provides a partial legal basis to grounded stakeholders to support the Rohingyas at the initial stage of emergency. However, such protection becomes more uncertain and confusing in the following months due to a lack of local government support and community resources. It is time for the Indonesia government to consider ratifying the 1951 Convention and 1967 Protocol, as well as initiate diplomatic pressure to Myanmar Government to stop the violation of human rights over the Rohingya people in its territory. 